UJMR, Volume 6 Number 1, June, 2021, pp 1 - 10

\title{
Prevalence of Urinary Schistosomiasis among Almajiri Children in Silame, Sokoto State,
} North-western Nigeria

\author{
${ }^{1}$ Gamde, S.M. ${ }^{1 D},{ }^{2}$ Tongvwam, P.J., ${ }^{1}$ Hauwa, K., ${ }^{3}$ Ganau, A.M., ${ }^{4}$ Abdulahi,J.A., ${ }^{5}$ Gamde, \\ D.S., and ${ }^{6} \mathrm{Choji}$, T.T.P \\ ${ }^{1}$ Department of Medical Laboratory Services, Hospital Services Management Board, Sokoto \\ State, Nigeria. \\ ${ }^{2}$ Department of Medical Laboratory Science, Faculty of Health Sciences and Technology, \\ University of Jos, Plateau State, Nigeria. \\ ${ }^{3}$ Departments of Microbiology, School of Medical Laboratory Sciences, UsmanuDanfodiyo \\ University, Sokoto State, Nigeria. \\ ${ }^{4}$ Department of Chemical Pathology, School of Medical Laboratory Sciences, UsmanuDanfodiyo \\ University, Sokoto State, Nigeria. \\ ${ }^{5}$ Department of Microbiology, Faculty of Natural Sciences, AbubakarTafawaBalewa University, \\ Bauchi State, Nigeria. \\ ${ }^{6}$ National Veterinary Research Institute, Jos, Plateau State, Nigeria. \\ Corresponding author:solomonmatthias85@gmail.com,08131943803
}

\begin{abstract}
Urinary schistosomiasis is a severe threat to global health with uncountable morbidities in Africa including Nigeria where control interventions focused on children in public and private schools neglecting Almajiri children. This undermined control interventions as those infected contaminate the environments with infective stages of the parasite. The objective of the study was to identify the prevalence of urinary schistosomiasis amongst Almajiri children in Silame, Sokoto State, North-western Nigeria. This was a cross-sectional descriptive study, socio-demographic data was collected in April 2020 on 206 consented Almajiri children in Silame and their urine samples were examined using the sedimentation method. The study showed a prevalence of $35.4 \%$ among the Almajiri children in Silame, Sokoto State, North-western Nigeria. The highest prevalence was found among children within the age range $16-20$ years $(63.6 \%)$ while the lowest prevalence was among those in the age range $6-10$ years $(24.4 \%)$. There was a statistically significant difference in the occurrence of urinary schistosomiasis between the age groups $\left(x^{2}=11.637^{a}, d f=3, p=0.002\right)$. Urinary schistosomiasis was prevalent among Almajiri children in the study area and parasite infection was associated with the participant's socio-demographic factors such as age, level of education, and water contact activities. Hence, the National Schistosomiasis Control Programs should incorporate the Almajiri children in the control interventions

Keywords: Schistosoma hematobium infection;Makarantarallo;Almajiri;Silame
\end{abstract}

INTRODUCTION

Urinary schistosomiasis, also known as Bilharziasis or Urogenital schistosomiasis is a severe threat to global health with uncountable morbidities in Africa countries caused by a digenetic trematode called Schistosoma hematobium of the Schistosomatidae family (Mudassiru et al., 2018). The parasite infects over 290.8 million people in the world (GHE, 2016) and caused about 280,000 deaths annually, a mortality figure challenged as a gross under estimate (Molyneux et al., 2016) with over700 million people at risk (WHO, 2016).Generally,schistosomiasis affects people of all ages in low resource settings including
Africa (Ballaet al., 2010) where Nigeria bears the highest morbidities with about 29 million cases predominantly in school-aged children (Mohammed et al., 2018).

In the year 2010, the World Health Organization prioritized schistosomiasis elimination campaigns through mass administration of drugs in endemic areas and targeted $75 \%$ morbidity reduction specifically in school-aged children by 2020. Although many countries including few in Africa made concerted efforts and eliminated the disease, it is now certain schistosomiasis eradication was unachievable in Nigeria and this may persist for another decade (Oyetunde et al., 2020). 
The national schistosomiasis campaigns by governments and non-governmental organizations in Nigeria always targeted children in public and private schools neglecting the Almajiri children attending Makarantar allo. This among other factors undermined schistosomiasis control effortsin Nigeria as those infected contaminate the environments with the infective stages of the parasite (Mohammed et al., 2015).

Makarantar allo, also known as Tablet or Slate school is derived from two Hausa language words; Makaranta (school) and Allo (slate) denote a traditional Islamic institution of learning the Holy Koran (Adams et al., 2012). The Non-native learners, the immigrant children encounter enormous challenges and have to fend for themselves under the guidance of a mallam (Islamic scholar) (Mohammed et al., 2015). Some unsettling characteristics ofthe Almajiri include being far from their parents, poor, living in over crowded rooms with poor access to health care servicesand are seen roaming almost every street and corner in the northern parts of Nigeria (Isiaka et al., 2015). People become infected with the cercariae stages of the parasite that penetrate the skin during water contact activities such asfarming, swimming, bathing, fetching water, or herding animals (Yunusa et al., 2016).

In the study area, the Almajiris constitute a majority of very low-skilled workforces (Yusha'u et al., 2013) where Sokoto Rima River Basin Development Authority executed considerable irrigation projects offers favourable environments for the survival of the intermediate host, Bulinus snail, and the causal agent of Bilharziasis, Schistosoma hematobium with little concern on the people's health's (Mudassiru et al., 2018).

Therefore, this study is designed to evaluatethe prevalence of urinary schistosomiasis and its association with some sociodemographic factors among Almajiri children in Silame, Sokoto State, North-western Nigeria.

\section{MATERIALS AND METHODS \\ Ethical consideration}

This study was approved by the Primary Healthcare Agency, Silame, Sokoto, Nigeria, and Silame Local Government Council (SLM/MOH/PHC/038/VOL.I.). Participants who were positive for the parasite were treated with praziquantel $(600 \mathrm{mg}$; Biltricide, Bayer, Leverkusen, Germany).

\section{Study setting and population} Statistical analysis
The study was conducted in twolslamic Schools, Gandu and Umaru Islamiya was selected by random sampling in Silame where epidemiological data on urinary schistosomiasis is scarce. Silame is the headquarter of the Local Government with an area mass of $790 \mathrm{Km}^{2}$ on Sokoto river located in the Sudan Savannah zone at the extreme Northwest, Nigeria between longitude $13^{0} 2^{1} \mathrm{~N}$ and latitude $4^{0} 51^{1} \mathrm{E}$ with apopulation of 104,378 people (NPC, 2006). Indigenous inhabitants are the Hausas and Fulani while other ethnic collections include Igbo, Yoruba, Ebira, Igala, and the Buxus from the Niger Republic with a growing number of Quranic Schools (SESP, 2010). Nonetheless, Silamepeople are very poor and dependent onthe Sokoto River for fishing, irrigation farming (Fadama in the Hausa language) fit for a variety of crops(Yusha'uet al., 2013).

Study Design and Subject SociodemographicCharacteristics

A cross-sectional descriptive study was conducted on206 Almajiri children at theGandu and Alhaji Umaru Islamiya in the Silame, Sokoto State, Nigeria, in April 2020. The sample size was estimated at 200 as described (Mohammed et al., 2018). A set of pretested, structured questionnaires on the Almajiri children such as age, religion, level of education, and father's occupation was used to determine the sociodemographic characteristics and schistosomiasis-related exposure.

\section{Parasitological assessment}

Urine samples were collected between 10:00 $A M$ and 2:00 PM in labeled-leak-proof universal sample containers and placed in black polyethylene bags to prevent the eggs from hatching into miracidia and then transported to the General Hospital Silame, Microbiology Laboratory for processing. The sedimentation method was used for the urine examination for the presence or absence of Schistosoma haematobium eggs. Seven milliliters of urine sample was transferred into a centrifuge tube and centrifuged at $1,000 \times \mathrm{g}$ for 5 minutes, the supernatant was decanted, and the residues were examined under $\mathrm{X} 10$ and $\mathrm{X} 40$ objectives using Olympus, USA (Albadawi et al., 2018).

Some Socio demographic characteristics of the eligible Almajiris

Socio-demographic information of the participant's name, age, sex, religion, area of residence, level of education, and father's occupations were obtained using a structured questionnaire that could be answered by a yes or no response with few are open-ended questions. 
The data obtained were analyzed using Statistical Package for Social Sciences Software (SPSSInc., Chicago, IL, USA) version 25.0.A descriptive and inferential analysis was determined at $p \leq 0.05$ level of significance.
Prevalence of Schistosoma hematobium among Almajiri Children in Silame, Sokoto State, North-western Nigeria

The study showed a prevalence of $35.4 \%$ $(73 / 206)$ among the Almajiri children in Silame, Sokoto State, North-western Nigeria. Considering the high morbidities of the parasite, a prevalence of $35.4 \%$ is a public health concern $(p=0.002)$. (Fig. 1$)$.

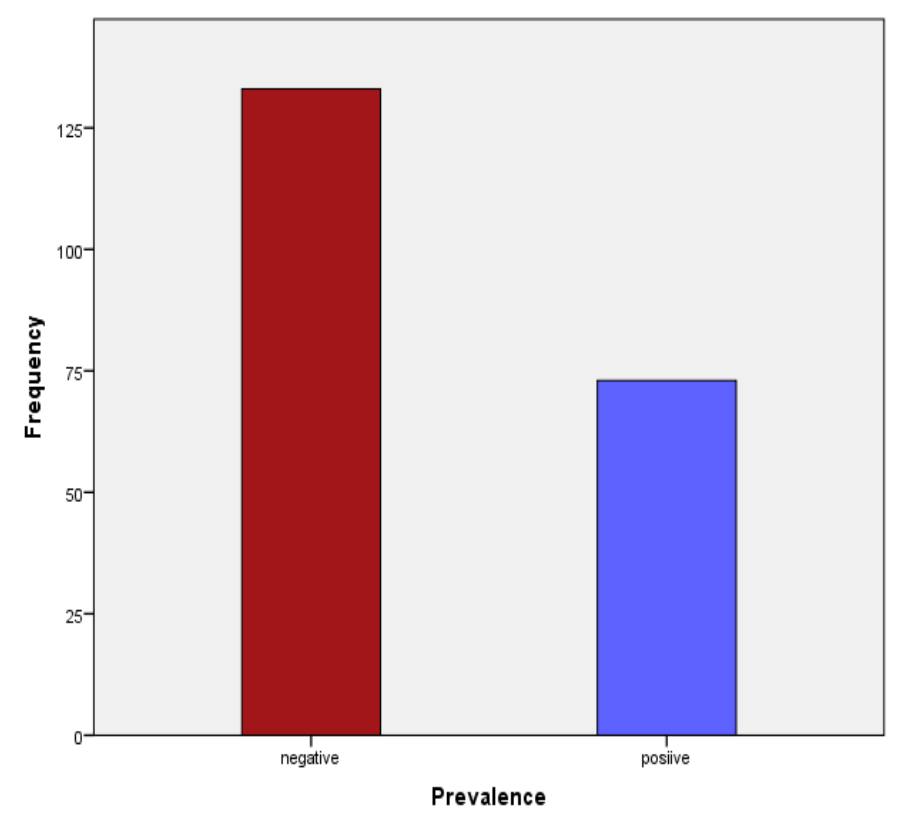

Fig. 1: Prevalence of Schistosoma hematobium among Almajiri Children in Silame, Sokoto State, North-western Nigeria.

Table 1: Distribution of Schistosoma hematobium based on the study sites

Regarding the study-based sites in Silame; Gandu and Umaru Islamiya, where epidemiological data on urinary schistosomiasis are scarce, the highest prevalence was recorded in Umarulslamiya (36.9\%) while the least prevalence was recorded in Gandu Islamiya (32.9\%). However, there was no statistically significant difference in the occurrence of urinary schistosomiasis between the two study-based locations $\left(x^{2}=.340^{a}, p=.560\right)$.

\begin{tabular}{lllll}
\hline Study sites & $\begin{array}{l}\text { Number } \\
\text { examined }\end{array}$ & Number infected & Prevalence (\%) & Statistics \\
\hline Gandu Islamiya & 76 & 25 & 32.9 & $\mathrm{x}^{2}=.340^{\mathrm{a}}, p=.560$ \\
Umaru Islamiya & 130 & 48 & 36.9 & \\
Total & 206 & 73 & 35.4 & \\
\hline
\end{tabular}

Socio-demographic characteristics of the Almajiri children

In relation to age, the highest prevalence was found among children within the age range 16 20 years $(63.6 \%, 7 / 11)$, while the lowest prevalence was among those in the age range 6-10 years $(24.4 \%, 20 / 82)$ (Fig. 2). There was a statistically significant difference in the occurrence of urinary schistosomiasis among the age groups $\left(x^{2}=11.637^{a}\right.$, df $\left.=3, p=0.002\right)$. However, no statistically significant difference was observed in the study-based locations $\left(x^{2}=.340^{a}, p=.560\right)$ and the participant's fathers' occupations $\left(x^{2}=.567^{a}, p=.753\right)$ (Table 2$)$. 


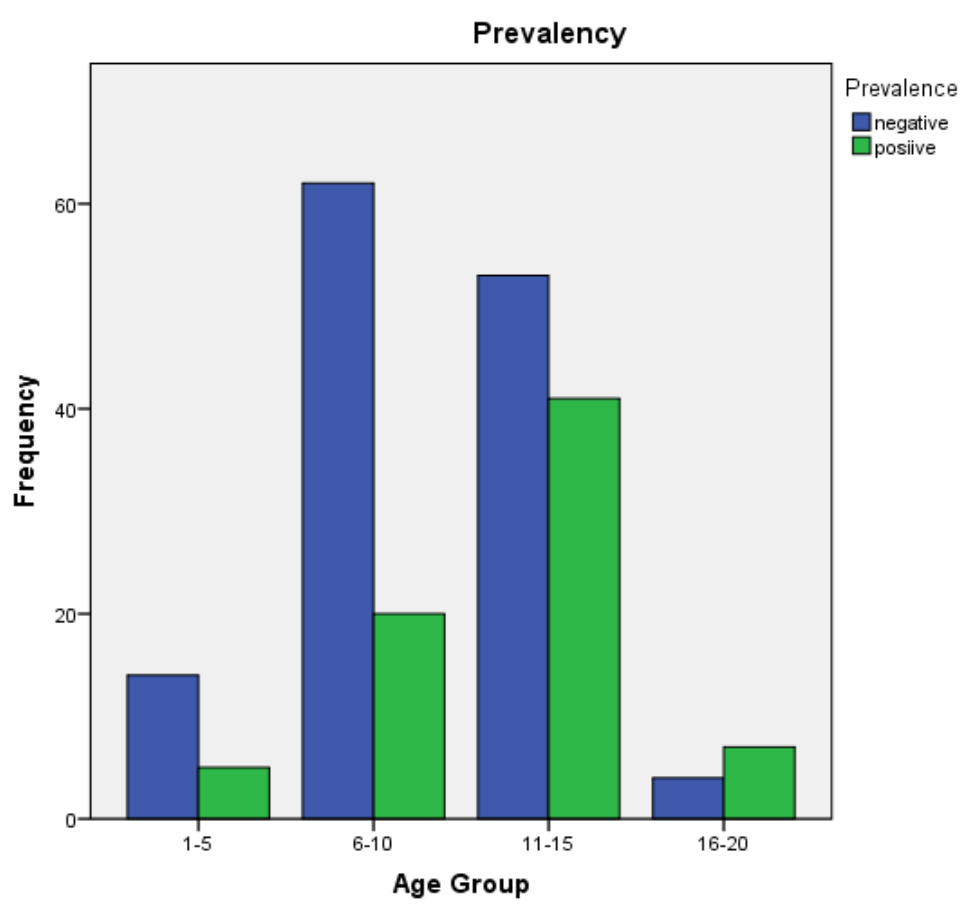

Fig. 2: Age distribution of Schistosoma hematobium among Almajiri Children in Silame, Sokoto State, North-western Nigeria.

Table 2: Some Socio-demographic Characteristics of the Almajiri children

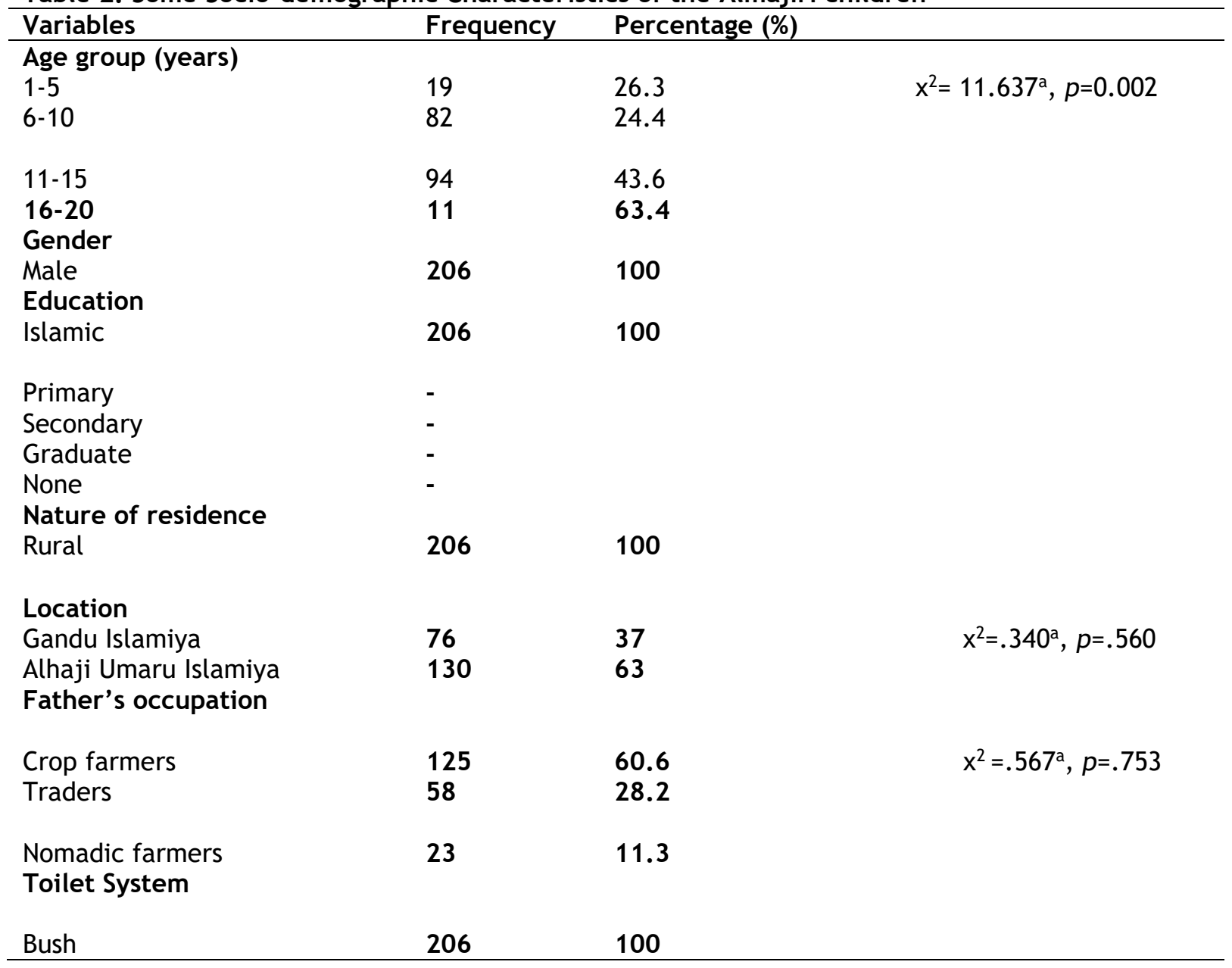




\section{DISCUSSION}

The prevalence of urinary schistosomiasis among Almajiri pupils in Silame was $35.4 \%$ $(73 / 206)$ (Fig. 1). This figure corroborates the pooled $34.7 \%$ prevalence of urinary schistosomiasis in Nigeria (Abdulkadira et al., 2017). Considering the high morbidities of the parasite, a prevalence of $35.4 \%$ is a public health concern and echoes the low socioeconomic and educational backgrounds of the study population (ICESC, 2016). Our result is consistent with other moderate prevalence of $33.5 \%$ in Wammako, Sokoto State, Northwestern Nigeria, $32.3 \%$ in Goronyo, Sokoto State, North-western Nigeria (Umar et al., 2008), 34.1\% in Enugu State, South-eastern Nigeria (Okechukwu et al., 2014), 34.2\% in Mayo-Belwa, Maiduguri, North-eastern Nigeria (Balla et al., 2015), and 37.7\% in Wurno, Sokoto State, North-western Nigeria (Bello et al., 2014).

However, other studies among Almajirs such as Balla et al. (2010) and Balla et al. (2012) reported higher prevalences of $74.0 \%$ in Gusau, Zamfara State, North-western Nigeria, and 75\% in Gwanje, BornoState, North-eastern Nigeria respectively. Frequent water contact activities in snail-infested rivers, poor level of literacy, and haphazard disposal of human sewage, and dearth of basic amenities are factors associated with urinary schistosomiasis. Lack of water supply and contamination of the few available water sources were attributed to the endemicity of urinary schistosomiasis among the Almajiri children.Besides, Almajiri children are always excluded inthe mass drug intervention for schistosomiasis in Nigeria which continues to contaminate the environments with the infective stage of the parasite (Mohammed et al., 2015).

The age distribution of schistosomiasis in the study area showed a rise in prevalence with the participant's age. The infection rises from $24.4 \%$ in the age range 6-10 years to a peak of $63.6 \%$ in the age range 16-20 years. There was a statistically significant difference in the

\section{REFERENCES}

Abdulkadira, M., Ahmed, B.M., Abubakar, I.E., Suleimana, I.Y., Imamdl.M., Sule, A.A., Tela,U.M., Dogoe ,H.M., Yakasai, A.M., and Musag, B.M.(2017). Prevalence of urinary schistosomiasis in Nigeria, 19942015: Systematic review and metaanalysis. .African Journal of Urology; 23: 228-239.

Adam, S., and AbdulWahid., A. (2012).Teaching Arabic as a second language in Nigeria. Procedia - Social and Behavioral Sciences, 66: 126-135.

UMYU Journal of Microbiology Research occurrence ofurinary schistosomiasis among the age groups $\left(x^{2}=11.637^{a}, \mathrm{df}=3, p=0.002\right)$ (Fig. 2). The age pattern of prevalence in the present study is consistent with previous studies that reported peak prevalence in the adolescence of the age group 16-18 years in Ondo state, Westsouth Nigeria (Akinneye et al., 2018), 11-20 years in Kano state, North-central Nigeria (Dawaki et al., 2016), and10-19 years in Gusau, Zamfara State, North-western Nigeria (Yandoma et al., 2019). Adolescence and young adults between ages $16-20$ years have a higher tendency to be engaged in water contact activities such as swimming, bathing, and farming than younger aged groups (Mudassiru et al., 2018). However, Awosolu et al.(2020) reported contrary to the present study and the difference could be attributed to the environmental settings, religious, and cultural practices with regards to water use (Ezeh et al., 2019).

\section{CONCLUSION}

Urinary schistosomiasis was prevalent among Almajiri children in Silame, Sokoto State, North-western Nigeria. Almajiri children within the age range $16-20$ years had the highest infection while the lowest prevalence was among those in the age range $6-10$ years. The difference in the occurrence of urinary schistosomiasis among the age groups was statistically significant $(p=0.002)$.

\section{RECOMMENDATIONS}

Based on the study, there is a need to incorporate Almajiri children in the National Schistosomiasis Campaigns organized by the governments and non-governmental organizations in Nigeria for appropriate intervention to combat the disease transmission.

We recommended research priority in areas of neglect and advocated for molecular techniques to increase the sensitivity of parasites.

Akinneye, J.O., Fasidi, M.M., Afolabi, O.J., and Adesina, F.P. (2018). Prevalence of Urinary Schistosomiasis among Secondary School Students in Ifedore Local Government, Ondo State, Nigeria. International Journal of Tropical Diseases, 1(004):1-6.

Albadawi, A., Talha, S.I., Abdlalla, E.M., Eltayeb, S.I., Elniama, A.A., Adam, D.A., Usama, E.A., and Bakri, Y.M.N.(2018). Prevalence of Intestinal and Urinary Schistosomiasis in Five Localities in Gezira State, Sudan. www.ujmr.umyu.edu.ng 
International Journal of Medical Science and Health Research, 2(3):8899.

Balla, H.J., Babagana, D.R., Baba, S., and Ibrahim, H. (2015). Incidence of Urinary Schistosomiasis amongst Out-of-School Pupils and "Almajiris" in Dikwa, NorthEastern Nigeria. Global Journal of Medical Research, Microbiology, and Pathology,15 (2): 9-13.

Balla, H.J., Zailani, S.B., Askira, M.M., Musa, A.B., and Mursal, A. (2010). Prevalence of urinary schistosomiasis amongst "Almajiris" and Primary School Pupils in Gwange Ward of Maiduguri. Borno Medical Journal (BOMJ), 7(2):7-10.

Bala, A.Y., Ladan, M.U., and Mainasara, M. (2012).Prevalence and intensity of urinary schistosomiasis in Abarma village, Gusau, Nigeria: A Preliminary Investigation, Science World Journal,7 (2):1-4.

Bello, A., Abdulgafar, O.J., Shittu, S.B., and Hudu, S.A. (2014). Prevalence of urinary schistosomiasis and associated haemato-proteinuria in Wurno Rural Area of Sokoto State, Nigeria. Oriented. Journalof Medicine, 26(3-4):114-121.

Dawaki, S., Al-Mekhlafi, H.M, Ithoi, I., Ibrahim, J., Abdulsalam, A.M., Ahmed, A., Sady, H., Atroosh, W.M., Al-Areeqi, M.A., Elyana, F.N., Nasr, N.A., and Surin, J.(2016). Prevalence and risk factors of schistosomiasis among Hausa communities in Kano State, Nigeria. Rev. Inst. Med. Trop. Sao Paulo, 2016: 54-58.

Ezeh, C.O., Onyekwelu, K.C., Akinwale, O.P., Shan, L., and Wei, H. (2019). Urinary schistosomiasis in Nigeria: A 50-year review of prevalence, distribution and disease burden. Parasite, 26:19.

Global Health Estimates (2016): Deaths by Cause, Age, Sex, by Country and by Region, 2000-2016. Geneva, World Health Organization, 2018.

Informal Consultation on Expanding Schistosomiasis Control in Africa view at

http: / /www. who.int/schistosomiasis/re sources/en/. [9 April 2016].

Isiaka, T.O. (2015). A Pilot Study of the Challenges of Infusing Almajiri Educational System into the Universal Basic Educational Programme in Sokoto, Nigeria. Journal of Education and Practice, 6(16): 10-17.

Mohammed, K., Suwaiba, M., Spencer, H.I., Nataala, S.U., Ashcroft, O.F., Nuhuand, A., and Asiya U.I. (2018). Prevalence of

UMYU Journal of Microbiology Research
Urinary Schistosomiasis among Primary School Children in Kwalkwalawa Area, Sokoto State, North-Western Nigeria. Asian Journal of Research in Medical and Pharmaceutical Sciences, 3(1): 110.

Mohammed, M., Vantsawa, P.A., Abdullahi, U.Y., and Muktar, M.D. (2015). Nutritional Status and Prevalence of Intestinal Schistosomiasis among Almajiri Population in Kawo District of Kaduna Metropolis, Kaduna StateNigeria. Journal of Bacteriology and Parasitology, 6: (237):1-5.

Molyneux, D.H., Savioli, L., and Engels, D. (2016). Neglected tropical diseases: progress towards addressing the chronic pandemic. Lancet; http://dx.doi.org/ 10.1016/S0140-6736(16)30171-4.

Mudassiru, I., Suleiman, A.B., Dibal, D.M., Abdulhamid, Y., and Abba, A.M. (2018). Prevalence of Urinary Schistosomiasis among School-Aged Children in Bakura Local Government Area of Zamfara State Nigeria. UMYU Journal of Microbiology Research, 3 (2): 7-13.

National Population Commission. (2006).Population and housing census priority table volume III: Population distribution by sex, State, Local Government Area, and Senatorial District (Electronic version). Abuja, Nigeria: National Population Commission, 2010.

Okechukwu, P., Ossai, D., Tukur, G., Eze, O., andEkwueme, O.C. (2014). Bacteriuria and urinary schistosomiasis in primary school children in rural communities in Enugu State, Nigeria. Pan African Medical Journal, 18:15.

Oluwaseun, B.A., Shariman,Y.Z., Farah, H.M.T., and Titus, A.O. (2020). Will Nigerians Win the War Against Urinary Schistosomiasis? Prevalence, Intensity, Risk Factors and Knowledge Assessment among Some Rural Communities in South-western Nigeria. Pathogens, 9(128): 1-13.

Oyetunde, T.O., Wander, J.J., Rafaella, F.Q.G. (2020). Schistosomiasis in Nigeria: Gleaning from the past to improve current efforts towards control. One Health, 100183 (11):1-8.

Schistosomiasis: WHO reports substantial treatment progress for school-age children? 2016. Availablefrom:http://www.who.int/neg lected diseases/news/WHO schistosomiasis reports substantial 
treatment progress sac/en/. Accessed July 30, 2019.

State Strategic Education Sector Plan (SESP) 2011 - 2020. Situation Analysis of Education in Sokoto State, 2010:1-33.

Umar, A.S, Ochei, M.,Arkilla, M.B., and Zailani, S.B. (2008). Prevalence and intensity of Urinary Schistosomiasis in settlements around Goronyo Dam, Nigeria. BOMJ, 5(2):4-10.

Yandoma, R.I., and Yohanna, S. (2019). Risk factors for intestinal parasitosis among Almajiri pupils in Zaria, North-Western Nigeria. Nigeria Journal of Basic Clinical Sciences, 16:60-3.
Yunusa, E.U., Awosan, K.J., Ibrahim, M.T.O., and Isah, B.A.(2016). Prevalence, epidemiological characteristics and predictors of the occurrence of urinary schistosomiasis among 'Almajiri' school children in Sokoto, Nigeria. International Journal of Medicine and Medical Sciences, 8(3): 22-29.

Yusha'u, M.A., Tsafe, A.K., Babangida, S.I., and Lawal, N.I. (2013). Problems and prospects of Integrated Almajiri Education in Northern Nigeria. Scientific Journal of Pure and Applied science, 2(3), 125-134. 